\title{
Corporate Communication Management Through The Corporate Social Responsibility Program In Developing Image And Reputation Of The Company
}

\author{
Erna Fatmawati ${ }^{1}$,Poppy Ruliana ${ }^{2}$, Irwansyah ${ }^{3}$, Niken Febrina Ernungtyas ${ }^{4}$ \\ \{ernafatmawati1973@gmail.com ${ }^{1}$, poppyruliana30@gmail.com ${ }^{2}$, \\ dr.irwansyah.ma@gmail.com ${ }^{3}$, niken@stikom.interstudi.edu \} \\ ${ }^{1,2,4}$ Sekolah Tinggi Ilmu Komunikasi (STIKOM) InterStudi, Indonesia \\ ${ }^{3}$ Universitas Indonesia, Indonesia
}

\begin{abstract}
The purpose of this research is to obtain information and clarity of corporate communication management models through CSR programs in building a corporate image. The concept of this research is based on Dowling Model Reputation Management Communication. This study was designed using a mix method that is a research approach that combines or associates qualitative and quantitative forms (Creswell, 2009). This study also combines explanatory research with descriptive research and testing of hypotheses. This research method uses a survey method with a multi-analysis approach that is descriptive analysis to see respondents' perceptions of corporate communication management through CSR programs in enhancing company image. Data collection is done through participant observation, in-depth interviews, document searches, literature and web site pages to obtain information and data related to research. Data analysis technique used structural equation model (SEM) analysis to determine the effect of corporate communication management variables through CSR programs on the company's image and reputation. The results showed that there was an effect of corporate communication management simultaneously on the company's image and reputation.
\end{abstract}

Keywords, corporate communication management, social responsibility, company image

\section{Introduction}

The subsequent implementation of Corporate Social Responsibility in brief CSR carried out by companies is based on policies issued by the Decree of the Minister of SOEs Number.KEP236 / MBU / 2003 dated June 17, 2003 and Law Number 40 of 2007 concerning Limited Liability Companies stipulated in July 2007 [1] In Chapter V article 74 mentions social and environmental responsibility, namely: First, limited liability companies carrying out their business activities in the field and or relating to natural resources are required to carry out social responsibility. The two social and environmental responsibilities as referred to in paragraph (1) are company obligations that are budgeted and calculated as company costs, the implementation of which is carried out with due regard to compliance and fairness. Third, the Company which does not carry out the obligation as referred to in paragraph (1) will be subject to sanctions in accordance with the provisions of the legislation. (in the commitment of the business / company 
to behave ethically and contribute to sustainable economic development, while improving the quality of life of employees and their families, the local community and the wider community. Fourth, the commitment of the business / company to behave ethically and contribute to sustainable economic development, while improving the quality of life of employees and their families, the local community and the wider community [2]

Based on the description above, it can be said the existence and role of the organization, in this case the PT Mifa Bersaudara company is inseparable from the role of government and society. In this case the role of the government as a guarantor of security and law enforcement and creating a conducive business climate will be crucial in the sustainability of PT Mifa Bersaudara and the community has an important role as a liaison between the government and companies. CSR itself is a commitment of the business / company to behave ethically and contribute to sustainable economic development, while improving the quality of life of employees and their families, the local community and the wider community. Thus CSR activities cover the company's internal and external activities by taking into account the needs and desires of stakeholders.

The form of CSR programs implemented by PT Mifa Bersaudara according to Nurza [3] PT Mifa Bersaudara carries out its social responsibility since the company started operating in West Aceh district. CSR is a form of commitment to actively participate in building society with the motto, "Grow, move forward and develop together with the people of Aceh". The concentration of the program is based on Community Empowerment which starts with the regional potential, aspirations and needs of the people of Aceh especially those around the mine, hauling roads and ports especially those around the mine, hauling roads and coal-specific ports which are based on the program implementation. 7 PT Mifa Bersaudara's CSR Pillar which is also an element of the sustainability development goals formulated by the United Nations as a reference to various community empowerment programs by adopting elements from ISO 26000. The implementation of this program is based on the company's vision and mission, CSR programs implemented include 1. Improvement Public Health.2. Active Participation in religious activities, social activities, and preservation of local culture. 3. Education and Training 4. Development of Village Facilities 5. Land-Based Resource Management 6. UMKM \& Entrepreneurship Partnership 7. Environmental Conservation \& Conservation of Biodiversity. [3]. This activity is carried out in the form of counseling, guidance or training so that the community can be independent. Assistance provided by companies in the form of capital, educational facilities, health, religious and so on. Assistance provided by companies in the form of capital, educational facilities, health, religious and so on is still top down communication. In this study, researchers focused on education because according to Azizon Nurza as CSR, Corporate Communication \& Land Matter Manager of PT Mifa Bersaudara see education as the most effective means of changing the mindset of the community to obtain a sustainable social license to operate by paying attention to the vision, mission of the organization and organizational policies.

However, in implementing CSR programs, it is important to pay attention to corporate communication management, even though companies must be able to communicate CSR programs in two directions so that communication processes occur reciprocally, both for internal and external companies, including the beneficiaries of the program. The results of previous research conducted by Nurjanah and Fizki [4] show that every company that implements CSR is required to have an understanding of effective CSR communication to stakeholders. The 
communication function becomes important in implementing CSR. The existence of effective communication between companies and communities that benefit from CSR programs will greatly determine the effectiveness of CSR programs. On the other hand, obstacles also come from the beneficiary community. CSR. For example, in research conducted by Amran [5], it shows that understanding of the concept and importance of CSR is still lacking in local communities in Malaysia, in contrast to developed countries where CSR ideas originate. This research also recommends that the community needs to understand their role in collaboration with companies to create sustainable lives, one of which is through dialogic communication. Furthermore, previous research conducted by [6] CSR Communication objectives is important, hence, indicating desired audience outcomes; e.g. raising awareness, awareness, participation and / or changes in individual behavior. Other research conducted by Siano A., Vollero A., Confetto M.G., Siglioccolo M. (7) states communication activities are built around relationships with several stakeholder groups. From this point of view, Corporate Communication Management (CCM) must have an important and active role in the organization's corporate strategy, "coordinating interdependent relationships to strategically contribute to overall company performance and capacity building." In addition, communication management not only creates awareness on sustainability initiatives but also enhance stakeholder identification, and stimulate interaction and collaboration between the company and its stakeholders on certain issues. From this perspective, CSR initiatives - or better corporate social response are important elements in building, improving and maintaining the company's reputation.

Based on these problems, the purpose of this study is to find out and explain the influence of corporate communication management models through corporate social responsibility programs on the image and reputation of the company PT Mifa Bersaudara.

\section{Research methods}

This study was designed using a mix method namely a research approach that combines or associates Creswell's qualitative and quantitative forms [18] This study also combines explanatory research with descriptive research and testing of hypotheses. This research method uses survey method which is a study conducted on large and small populations but the data studied data from samples taken from these populations, so that the relative events, distribution, and relationships between sociological and psychological variables are found [19] with an approach multi analysis is a descriptive analysis by describing the events that occur Sampling in a puposive manner so as to obtain 130 respondents who participated in the education and training program organized by PT Mifa Bersaudara. Data collection is done through participant observation, in-depth interviews, document searches, literature and web site pages to obtain information and data related to research. The data analysis technique is used structural equation model analysis (SEM) to determine the effect of corporate communication management variables through CSR programs on the company's image and reputation.

\section{Research Results And Discussion}

The results of this study are reviewed in three sub discussion of the findings obtained in the exploration, review and review of information and data related to the research topic. The first finding concerns the validity and reliability obtained from distributing questionnaires and being tested hypothetically. The second finding is the effect of communication management through 
CSR programs on corporate image. The third finding about the effect of communication management through CSR programs on company reputation and the fourth finding about the effect of communication management through CSR programs on the image and company.

\section{Testing the Assumptions of the Structural Equation Model}

The process of testing the requirements analysis in this study is a requirement that must be met so that the use of regression techniques that are included in the parametric statistical group can be applied for hypothesis testing. Testing the requirements analysis performed is the normality of the regression error. Testing the error normality requirements in the Structural Equation Model (SEM) is done with a view to knowing whether the data distribution does not deviate from the characteristics of normally distributed data. This normality requirement test is performed on univariate and multivariate estimated error based on the output of the amos application analysis. Testing the normality of errors in the SEM model is tested through the following hypothesis:

Ho: The error in the SEM model is normally distributed

$\mathrm{H} 1$ : errors in SEM model are not normally distributed

Decision making provisions if the value of the critical ratio (c.r.) is located at intervals of 2.58 to 2.58 , it does not reject $\mathrm{H} 0$, meaning that the estimated error in the SEM model is normally distributed. The results of the normality test for structural equation model path diagram of structural models based on the output of amos output are listed in Table 1 below, the lowest c.r univariate value is $-1,210$ and the highest is 1,989 (5th column). These values are at intervals of $-2.58<$ c.r $<2.58$, so do not reject $\mathrm{H} 0$ or model errors in the structural equation normally distributed. Thus, it can be concluded that the errors in the SEM model formed are normally distributed.

Table 1 Testing for the Normality of Structural Equation Model Errors

\begin{tabular}{|l|rrrrrr|}
\hline Variable & $\min$ & $\max$ & skew & c.r. & kurtosis & c.r. \\
\hline CR_4 & 2.000 & 5.000 & -1.014 & -4.610 & .346 & .785 \\
CR_3 & 1.000 & 5.000 & -1.356 & -6.164 & 1.989 & 4.520 \\
CR_2 & 2.000 & 5.000 & -.997 & -4.534 & .268 & .610 \\
CR_1 & 2.000 & 5.000 & -.718 & -3.264 & -.473 & -1.075 \\
CI_3 & 2.000 & 5.000 & -.254 & -1.153 & -1.210 & -2.750 \\
CI_2 & 1.000 & 5.000 & -.566 & -2.575 & -.231 & -.526 \\
CI_1 & 2.000 & 5.000 & -.272 & -1.239 & -1.009 & -2.294 \\
CM_1 & 2.000 & 5.000 & -.346 & -1.572 & -.965 & -2.193 \\
CM_2 & 1.000 & 5.000 & -.490 & -2.226 & -.229 & -.520 \\
CM_3 & 2.000 & 5.000 & -.315 & -1.434 & -1.108 & -2.518 \\
Multivariate & & & & & 105.289 & 37.841 \\
\hline
\end{tabular}




\section{Estimating the Parameters and Testing}

Testing the estimating coefficient of the parameters of the structural equation model indicator is done through testing the following hypotheses:

H_0 : b_1 = b_2 = 0

$\mathrm{H} \_1:$ there is one different value of $b$

Testing Conditions. if the value of sig. $\alpha=0.05$. then reject $\mathrm{H} 0$ or the estimation coefficient is significant at the real level $\alpha$. Based on Table 2, all of the ewom indicators, brand attitude indicators and purchase intention indicators have a P-value less than $\alpha$ of 0.05 , so reject $\mathrm{H} 0$. Thus it can be concluded that the ewom indicator, brand attitude indicator and purchase intention indicators significantly influence the latent variables of ewom, brand attitude and purchase intention directly at the real level of $5 \%$.

The estimation coefficient of corporate communication management towards company image is 1,619 with a p-value of $0,000<\alpha$ of 0.05 , then reject $\mathrm{H} 0$. That is, communication management has a direct effect on the company's image and is evident at the 5\% level. This shows that the communication management carried out by PT Mifah Brothers is based on the company's vision and organizational culture and interpersonal communication takes place effectively in the implementation of CSR programs in the form of education and training is received well by the trainees so as to form a positive image of the CSR participants which is based on impression, belief and attitude. Furthermore, the understanding and image formed among the employees will determine the effectiveness of verbal communication with all members of the constituency outside. The effectiveness of this oral communication in turn will affect the formation of the company's image among interest groups outside it. In forming the company's image among outside groups it is also influenced by formal policies of the company. That way the image of the outside group is hit by the flow of information coming from three different sources, namely formal company policies, marketing communication media, and verbal or interpersonal communication with employees who already have an internal image of the organization. The two formal communications - organizational policies and marketing communications media - also indirectly exert influence on the image of outside groups, namely through the image of employees. But in accordance with the theory of attitude formation, both communication originating from formal sources has an influence on the level of information, while verbal communication on the level of affection and attitude. In this way, the employee's image - an internal image - is a very important source of influence that requires serious and consistent attention from the leader, in order to have a positive influence on the image of the outside group. In addition, it should be remembered that the external image is still influenced by oral communication networks - interpersonal inter-constituents outside the company - and experience with the quality of products and services in the past, and the chain of distribution of goods or services from the company. In short, the image of the organization in the minds of stakeholders outside the organization is a complex problem that must be handled carefully and consistently.

Then the parameters of the latent variable of communication management on the company's reputation of 0.662 with a p-value of $0.000<\alpha$ of 0.05 , then reject H0. That is, communication management directly affects the company's reputation at a real level of $5 \%$. The direct influence of corporate communication management through CSR programs in the form of education and training on the company's reputation because the company's image for employees and 
stakeholders has been formed. Reputation is seen from the company's competence, company excellence, trust in the company and the company's experience in implementing CSR programs. Furthermore, internal communication channels, such as various policy documents, manuals, brochures, announcements, briefings, and various formal meetings, have a very large role in this process. Management communication and corporate image among employees are influenced by 'organizational culture' (organizational culture), which acts as an 'overall social setting'. Organizational culture, openness, and participation, or vice versa, closure greatly determines the effectiveness of corporate communication management about the company's reputation for its own employees, because the culture of the organization will affect not only the clarity and understanding of the company, but also the openness of employees to deliver feedback on various company policies.

In addition, all parameters of the indicator variables of the latent variables of communication management, company image and company reputation have a p-value of $0,000<\alpha$ of 0.05 , so reject $\mathrm{H} 0$. That is, communication management indicator variables, company image and company reputation directly influence each latent variable at the 5\% level.

Table 2 Estimating Parameters and Testing Parameters

\begin{tabular}{|c|c|c|c|c|c|c|}
\hline & & & Estimate & S.E. & C.R. & $\mathrm{P}$ \\
\hline IMAGE & $<--$ & MANAGEMENT & 1.619 & .199 & 8.136 & $* * *$ \\
\hline REPUTATION & $<--$ & MANAGEMENT & 662 & .100 & 6.645 & $* * *$ \\
\hline CM_3 & $<--$ & MANAGEMENT & 1.000 & & & \\
\hline CM_2 & $<--$ & MANAGEMENT & 1.204 & .181 & 6.652 & $* * *$ \\
\hline CM_1 & $<--$ & MANAGEMENT & 1.526 & .189 & 8.075 & $* * *$ \\
\hline CI_1 & $<--$ & IMAGE & 1.000 & & & \\
\hline CI_2 & $<--$ & IMAGE & .778 & .083 & 9.355 & $* * *$ \\
\hline CI_3 & $<--$ & IMAGE & .894 & .070 & 12.791 & $* * *$ \\
\hline CR_1 & $<--$ & REPUTATION & 1.000 & & & \\
\hline CR_2 & $<--$ & REPUTATION & .947 & .099 & 9.536 & $* * *$ \\
\hline CR_3 & $<--$ & REPUTATION & 1.052 & .105 & 10.053 & $* * *$ \\
\hline CR_4 & $<--$ & REPUTATION & .975 & .088 & 11.054 & $* * *$ \\
\hline
\end{tabular}

\section{Goodness of Fit Second Structural Equation Model}

The goodness of the second structural equation model can simultaneously be determined from the magnitude of some goodness of fit values listed in Table 3. Terms of testing the chi square value. if the value of $X_{-}$count ${ }^{\wedge} 2$ is small or <table. then the model is decent. Next. if the value of sig. $>\alpha=0.05$. then the model is decent. Other than that. the model is said to be feasible if it has an RMSEA value $\leq 0.08$. GFI and AGFI $\geq 0.90$ and TLI and CFI values $\geq 0.95$. 
Table 3 Goodness Of Fit Structural Equation Model First

\begin{tabular}{llll}
\hline \multicolumn{1}{c}{ Goodness of Fit Index } & \multicolumn{1}{c}{ Cut off Value } & Nilai Hitung & Keterangan \\
\hline $\mathrm{X}^{2}-$ Chi Square & Kecil & $55.695>42.56$ & poor fit \\
Significant Probability & $\geq 0.05$ & 0.002 & poor fit \\
RMSEA & $\leq 0.08$ & 0.087 & poor fit \\
GFI & $\geq 0.90$ & 0.913 & good fit \\
AGFI & $\geq 0.90$ & 0.835 & poor fit \\
TLI & $\geq 0.95$ & 0.963 & good fit \\
CFI & $\geq 0.95$ & 0.976 & good fit \\
\hline
\end{tabular}

Based on Table 6. X_calculated value ${ }^{\wedge} 2$ obtained 55.695 which is greater than t_table for 42.56. The significance value of 0.002 is smaller than $\alpha$ of 0.05 . RMSEA value of 0.087 is greater than the value of 0.08 . GFI value of 0.913 is greater than the critical value of 0.90 . AGFI value of 0.835 is smaller than the critical value of 0.90 . Then. TLI and CFI values of 0.963 and 0.976 are greater than the critical value of 0.95 . This means that most of the goodness of the model does not meet the value of criticism except the GFI, TLI and CFI criteria. Thus it can be concluded that the estimated parameters produced by the second structural equation can be used for modeling, however, the simultaneous second structural equation model still needs improvement in order to obtain a more precise estimate.

\section{Conclusions}

The estimation coefficient of corporate communication management towards company image is 1,619 with a p-value of $0,000<\alpha$ of 0.05 , then reject H0. That is, communication management has a direct effect on the company's image and is evident at the $5 \%$ level. This shows that communication management based on organizational policies, work culture and interpersonal communication carried out by PT Mifah is effective in implementing CSR programs in the form of education and training received well by trainees so that they can form a positive image of CSR participants which is based on impression, belief and attitude.

The parameter of latent communication management to the company's reputation is 0.662 with a p-value of $0.000<\alpha$ of 0.05 , then reject $\mathrm{H} 0$. That is, communication management directly affects the company's reputation at a real level of $5 \%$. The direct influence of corporate communication management through CSR programs in the form of education and training on the company's reputation because the company's image for employees and stakeholders has been formed. Reputation is seen from the company's competence, company excellence, trust in the company and the company's experience in carrying out CSR programs

However, the significance value of 0.002 is smaller than $\alpha$ of 0.05 , indicating that the image and corporate reputation variable on corporate communication management quite influential on corporate communication management. There are other factors not examined that affect this 
research, namely communication channels, perceptions of the participants of CSR Education and training lack understanding of the material presented.

Thus, it can be suggested that PT Mifa Bersaudara should increase the use of communication channels in implementing CSR programs and also pay attention to the context of communication to be carried out and consider the targeted audiences.

\section{Referensi}

[1] Adhianty Nurjanah1, Frizki Yulianti, 2019. Pelaksanaan Program Corporate Sosial Responsibility (Csr) Dan Komunikasi Csr (Studi Kasus: Csr Delegation European Union To Malaysia Dan Csr Pt. Holcim Indonesia Tbk. Cilacap Plant), Profetik Jurnal Komunikasi, ISSN: 1979-2522 (print), ISSN:2549-0168 (online).

[2] Ruliana, Poppy, 2016. Komunikasi Organisasi, Teori dan Studi Kasus, Edisi Ke dua. Jakarta: RajaGrafindo Persada.

[3] Nurza, Azizon, 2019. Berita Mifa Bersaudara, Web Mifa Bersaudara.

[4] Adhianty Nurjanah1, Frizki Yulianti, 2019. Pelaksanaan Program Corporate Sosial Responsibility (Csr) Dan Komunikasi CSR (Studi Kasus: Csr Delegation European Union To Malaysia Dan Csr Pt. Holcim Indonesia Tbk. Cilacap Plant), Profetik Jurnal Komunikasi, ISSN: 1979-2522 (print), ISSN:2549-0168 (online).

[5] Amran, Azlan, Mustaffa Mohamed Zain, Maliah Sulaiman, Tapan Sarker and Say Keat Ooi. (2013). Empowering Society For Better CSR : The Case of Malaysia, Kajian Malaysia, Vol. 31, No.1, pp.57-78

[6] Nayan Mitra, Asif Akhtar and Ananda Das Gupta, 2018. Communicating Corporate Social Responsibility in the post mandate period: Evidence from IndiaInternational Journal of Corporate Social Responsibility.

[7] Siano A., Vollero A., Confetto M.G., Siglioccolo M. (2013), “Corporate communication management: A framework based on decision making with reference to communication resources”, Journal of Marketing Communications, Vol.19, n. 3, pp. 151-167.

[8] Andre Harjana, 2008. Komunikasi dalam Manajemen Reputasi Korporasi, Jurnal Ilmu Komunikasi, Volume 5, Nomor 1, Juni 2008.

[9] Anne Ellerup Nielsen and ChristaThomsenn, Investigating CSR communication in SMEs: a case study among Danish middle managers, Business Ethics: A European Review Volume 18 Number 1 January 2009.

[10] Grahame R. Dowling, dalam Harjana, 2018. Komunikasi dalam Manajemen Reputasi Korporasi, Jurnal Ilmu Komunikasi, Volume 5, Nomor 1, Juni 2008.

[11] Cornelissen, J.P. (2011), Corporate Communications: A Guide for Theory and Practice. 3 ed. Thousand Oaks, CA, Sage Publications Ltd.

[12] Worcester, R. M., dalam Kuang-Hui Chiu* and Chien-Lung Hsu, Research On The Connections Between Corporate Social Responsibility And Corporation Image In The Risk Society: Take The Mobile Telecommunication Industry As An Example. International Journal of Electronic Business Management, Vol. 8, No. 3, pp.183-194 (2010).

[13) Dowling, G. R., 1986, dalam Kuang-Hui Chiu* and Chien-Lung Hsu, Research On The Connections Between Corporate Social Responsibility And Corporation Image In The Risk Society: Take The Mobile Telecommunication Industry As An Example. 
International Journal of Electronic Business Management, Vol. 8, No. 3, pp.183-194 (2010).

[14] Nguyen, N. O. \& Leblanc, G., 2001, "Corporate Image And Corporate Reputation In Customer's Retention Decision In Services," Journal of Retailing and Consumer Services, Vol. 8, No. 4, pp. 227-236.

[15] Fombrun, C.J. 1996. Reputation: Realizing Value from the Corporate Image. Boston, MA: Harvard Business School Press.

[16] Ruliana, Poppy, 2014. Komunikasi Organisasi, Teori Dan Studi Kasus, Jakarta: RajaGrafindo.

[17] Neda Vitezić, 2011. Corporate Reputation And Social Responsibility: An Analysis Of Large Companies In Croatia. International Business \& Economics Research JournalAugust 2011 Volume 10, Number 8. 